\title{
Agricultura familiar em busca de renda monetária e a relativização da sustentabilidade
}

Eliziário Noé Boeira Toledo ${ }^{1}$

Valdecir José Zonin ${ }^{2}$

\begin{abstract}
Resumo
$\mathrm{O}$ artigo buscou problematizar se as necessidades de renda extraordinária dos agricultores familiares relativizam a adoção de práticas produtivas amigáveis às demandas da sustentabilidade ambiental. Visou apresentar indicadores de excedentes monetários e das práticas sustentáveis, que porventura tenham sido adotadas pelos agricultores familiares no desenvolvimento das atividades agropecuárias. Foi adotada a modalidade de estudo de caso levantando as informações por meio da coleta de dados quantitativos realizadas no ano de 2019, utilizando questionários padronizados aplicados aos 54 informantes localizados nos municípios de Sertão, Barão de Cotegipe e Viadutos, região do Alto Uruguai do estado do Rio Grande do Sul, e complementadas por mais 10 entrevistas qualitativas. Utilizou-se os argumentos teóricos defendidos pela Perspectiva Orientada ao Ator (POA) e da agência humana. Os dados permitiram aludir que as demandas defendidas pela sustentabilidade ambiental estão sendo preteridas como prioridades dos agricultores, cujos recursos, infraestrutura, habilidades produtivas e técnicas foram alocadas na produção prioritária de excedentes econômicos.
\end{abstract}

Palavras-chave: Práticas sustentáveis. Agricultura familiar. Excedentes econômicos.

\section{Family farming in search of monetary income and the relativization of sustainability}

Abstract

The article sought to problematize whether the extraordinary income needs of family farmers relativize the adoption of productive practices that are friendly to the demands of environmental sustainability. It aimed to present indicators of monetary surplus and sustainable practices, which have been adopted by family farmers in the development of agricultural activities. The modality of case study was adopted by raising the information by collecting quantitative data, held in 2019, using standardized questionnaires applied to 54 informants located in the municipalities of Sertão, Barão de Cotegipe and Viadutos, Alto Uruguai region in the state of Rio Grande do Sul, and complemented by 10 more qualitative interviews. The theoretical arguments defended by the actor-oriented perspective (AOP) and the human agency were used. The data allowed us to allude that the demands defended by environmental sustainability are being deprecated as farmers' priorities, whose resources, infrastructure, productive and technical skills were allocated in the priority production of economic surplus.

Keywords: Sustainable practices. Family farming. Economics surpluses.

\footnotetext{
1 Doutor em Desenvolvimento Sustentável (UnB). Membro do Grupo de Pesquisa Agricultura Familiar e Transição Agroecológica da Universidade Federal da Fronteira Sul (UFFS). Email: enbtoledo@gmail.com Orcid: 0000-0001-7919-9371.
}

2 Doutor em Agronegócios (UFRGS). Professor do Programa de Pós-Graduação em Ciência e Tecnologia Ambiental da Universidade Federal da Fronteira Sul (UFFS), campus Erechim. Email: valdecir.zonin@uffs.edu.br

Orcid: $0000-0002-3021-4275$. 


\section{Introdução}

O conjunto de transformações nas regiões rurais desde o início da modernização da agricultura brasileira, a partir da década de 1960, deslocaram mais de cinquenta milhões de pessoas das áreas rurais para os centros urbanos (IBGE 2010). Por conseguinte, produziram profundas marcas nas regiões rurais e na sociedade brasileira. Apesar disso, uma parte da academia e das representações políticas dos agricultores, ainda parecem "olhar o rural por meio de um retrovisor quebrado". Essa perspectiva denota o receio ou desatenção em admitir que a agricultura, os agricultores e o mundo rural se transformaram radicalmente. Inclusive, pela adoção uma nova racionalidade econômica e instrumental, sedimentando outros comportamentos sociais de sobrevivência e competição, pressionando os agricultores à novas demandas políticas da sociedade.

Uma delas é a preocupação com as demandas ambientais, ao se instalar como uma nova ordem do dia, ao se tornar em mais uma das modalidades de tarefas depositadas na conta dos agricultores. Isso está ocorrendo na medida em que parte dos consumidores, na maioria urbanos, estão buscando alimentos seguros, limpos e livres de contaminantes químicos e biológicos, exigindo produtos "politicamente sustentáveis", com os cuidados com o meio ambiente.

A questão que norteia a reflexão deste artigo é se as necessidades de ingresso de renda extraordinária (ou excedente) nos estabelecimentos dos agricultores familiares, de alguma forma, estão relativizando a adoção de práticas produtivas que sejam mais amigáveis às demandas da sustentabilidade ambiental, que se apresentam como uma demanda imposta, especialmente pelos extratos sociais mais bem situados economicamente. Essa abordagem e essa demanda se impõem como uma responsabilidade erroneamente atribuída, quase exclusivamente, aos agricultores e às populações rurais.

Diante do exposto, o objetivo do estudo foi buscar e apresentar indicadores de excedentes monetários e de uso de práticas e/ou tecnologias sustentáveis, que porventura tenham sido adotadas pelos agricultores familiares, no desenvolvimento das atividades agropecuárias realizadas nos seus estabelecimentos. A pesquisa foi realizada em estabelecimentos rurais dos municípios de Sertão, Barão do Cotegipe e Viadutos, localizados na região do Alto Uruguai do estado do Rio Grande do Sul.

A artigo está organizado em cinco seções, além desta brevíssima introdução. A segunda 
seção trata dos aspectos relacionados com as expressões teóricas-analíticas do ator e agência. Essas perspectivas se traduzem na arte de ver, ler, interpretar a realidade e escolher as melhores opções, de acordo com o portfólio de escolhas, alternativas e recursos sociais, culturais e econômicos, das quais os agricultores familiares têm acesso. Com a finalidade de amparar a ação, a terceira seção abordou a ideia plástica e polissêmica de sustentabilidade, a quarta versou sobre os aspectos referentes à importância da cultura da soja, a expressão socioeconômica como geradora de excedentes monetários. A quinta seção ilustra a preocupação ambiental observada pela lógica dos agricultores familiares e, por fim, apresentam-se as considerações finais.

\section{Ator e agência, a arte de ler, interpretar e escolher}

As bases econômicas da produção agrícola de uma forma ou de outra estão assentadas sobre as necessidades de integração econômica. No Brasil, foi arguta e precisa a visão de Antônio Cândido, ao estudar os comportamentos sociais dos caipiras de Bofete, no interior de São Paulo, ainda na década de 50, ao perceber os sinais dessas mutações, ainda que rudimentares. As formas de fazer agricultura, vem sendo radicalmente transformadas desde os meados da década de 60, e potencializadas na década de 1970, pelo advento da modernização da agricultura. Esse processo, ao introduzir um conjunto articulado de inovações institucionais, creditícias, técnicas e mercadológicas, sociais, econômicas e culturais, sedimentou novos comportamentos entre os agricultores e decompôs as feições das regiões rurais. Em Buainain et al., 2013; e Buainan et al., (2014) aludem a emergência do novo padrão de desenvolvimento na agricultura, que ocorreu pela introdução de inúmeras modalidades mais exigentes dos novos consumidores, aporte de tecnologias e estratégia de gestão, adoção de políticas gerais e setoriais adotadas pelo Estado, a crescente intensificação tecnológica, cada vez mais combinada como o acirramento concorrencial. Esses fatores vêm influenciando o funcionamento da economia e da sociedade, que combinados, produziram outro tipo de racionalidade, que refletem de forma hegemônica nas dinâmicas produtivas da agropecuária brasileira. Essas condições potencializaram a dimensão econômica de um fenômeno novo, financeirização da agricultura, expressa por meio da introdução sistemática do:

[...] capital "em todas as suas modalidades" no centro do desenvolvimento agrícola e 
agrário. Rebaixa o papel da terra, pois a produção e as rendas agropecuárias passam a depender, crescentemente, dos investimentos em infraestrutura, máquinas, tecnologia e na qualidade da própria terra, além de investimentos em recursos ambientais e no treinamento do capital humano. Cada vez mais é preciso capital de giro para introduzir no sistema produtivo os insumos que viabilizam as inovações para manter-se rentável em ambientes de crescente tensionamento concorrencial (BUAINAIN et al., 2013, p. 110, grifos no original).

Dessa forma, está presente na literatura sobre a modernização o ponto de vista que apregoa que o desenvolvimento surge de formas mais elementares e básicas e convergem progressivamente para formas mais complexas, respondendo às estratégias institucionais e tecnológicas disponíveis. As abordagens da economia política (especialmente, as concepções marxistas e neomarxistas) exacerbaram as modalidades para concretizar a mais-valia e a acumulação de capital (LONG, 2001; 2007). Esses enfoques deterministas, a priori, não conferiram perspectiva de leitura, reação e mesmo de ação prática aos indivíduos, em face das ingerências dos agentes externos, supondo que eles passivamente acatavam, sem esboçar reações.

A "perspectiva orientada ao ator" (POA) foi desenvolvida inicialmente por Norman Long (LONG, 2001). A análise focava nos processos de mudança econômica e social no cotidiano dos agricultores familiares, a partir da alocação e das influências das políticas públicas externas, com o objetivo de alavancar o desenvolvimento rural no continente europeu. Long (2001) buscava compreender as intervenções externas para promover o processo de desenvolvimento e, observados pela ótica dos agricultores. Ao dar voz a quem foi considerado um agente passivo e que acatava sem esboçar reações, abriu um promissor campo de estudo e permitiu a elaboração de políticas públicas mais eficientes e adequadas à realidade para viabilizar o desenvolvimento rural.

Os agricultores familiares, ao exercitar a condição de agente/ator, elaboram uma espécie de "cálculo" sobre os constrangimentos e possibilidades no circuito das relações sociais que fazem parte da vida cotidiana. Esse "cálculo" representa uma resposta à situação de ameaça à reprodução social na condição de agricultor (GARCIA JÚNIOR, 1989) e, da mesma forma, arregimenta informações para interpretar e agir. A condição de ator dos agricultores, segundo Long (2001), evidenciou a heterogeneidade no meio rural, evidenciando as distintas racionalidades que apoiam as ações, desejos e capacidades que amparam as práticas. Anteriormente, Long (1982) já havia trazido à tona dois temas relevantes para o debate sobre o desenvolvimento rural. $O$ primeiro trata das barreiras que bloqueiam ou dificultam a 
transformação dos valores tradicionais dos agricultores (e por extensão, das organizações de representação), que por vezes emperram a concretização do desenvolvimento rural. O segundo tema trata da necessidade de identificar e isolar os elementos facilitadores do arranque econômico na busca do lucro. Esse assunto quase sempre é ignorado ou negligenciado pela visão anticapitalista da agricultura, perspectiva comum nos países latinos americanos e, em especial, no Brasil (NAVARRO, 2016).

Nessa mesma perspectiva, Abramovay (2012, p. 137-138) enfatizou de forma categórica que "[...] Aquilo que era antes de tudo um modo de vida, se converteu numa profissão, numa forma de trabalho" e "[...] A competição e a eficiência convertem-se em normas e condição de reprodução social”. Esses fatores se tornaram objetos de análise social, econômica e cultural, ao serem interpretados como uma peculiaridade que vem se exacerbando, especialmente a partir da década de 1990, por conta da ampliação do processo de monetarização da vida social dos agricultores (NAVARRO, PEDROSO, 2011; BUAINAIN et al., 2014, TOLEDO, 2017). A busca por viabilização da esfera econômica se tornou o centro das preocupações dos agricultores, na medida em que a agricultura se tornou cada vez mais uma atividade regulada pelo mercado. Essas possibilidades são interpretadas como condições para permanecer na atividade, independentes do tipo ou tamanho dos estabelecimentos e, logicamente, se trata de um processo seletivo. Por outro lado, é a mesma racionalidade do ator que escolhe ou é induzido a escolher e interpretar como facilidades a serem aproveitadas, por meio da aquisição de máquinas e insumos agrícolas em condições diferenciadas. Deve ser ressaltado que são tentativas nem sempre bem-sucedidas de melhorar e aumentar as condições de produção, elevar a produtividade da terra e do trabalho por meio de programas de financiamentos apoiados com recursos públicos. Como exemplo de programa, cita-se o "Mais Alimentos", que apesar de necessário, amplia a diferenciação social ao apostar nos agricultores mais capitalizados que optam, desejam deliberadamente ou são compelidos a se modernizar diante do risco de exclusão do processo produtivo (AQUINO, SCHNEIDER, 2015).

A partir das contribuições teóricas de Norman Long e Jan Douwe Van der Ploeg e outros, o Programa de Desenvolvimento Rural da Universidade Federal do Rio Grande do Sul (PGDRUFRGS) e o Grupo de Estudos e Pesquisas Agricultura Familiar e Desenvolvimento Rural (GEPAD) desenvolveram trabalhos de pesquisa acadêmica, na tentativa de adequar os pressupostos teóricos da POA às características e necessidades brasileiras. O esforço resultou na elaboração de vários trabalhos (SCHNEIDER, GAZOLLA, 2011; CONTERATO et al., 2011, 
TOLEDO, 2009; CARAVALHEIRO, GARCEZ, 2007; NIEDERLE, 2007). A utilização da POA, ao dar voz às interpretações personalizadas dos agricultores familiares, se constituiu em ferramenta teórica pertinente e apropriada para compreender a intenção, a racionalidade e as ações, por vezes, desconsideradas, que os agricultores rotineiramente adotam visando atender às suas necessidades.

As estratégias são utilizadas para administrar seus estabelecimentos e para agir e reagir aos constrangimentos externos a que são constantemente submetidos. Desta forma, os indivíduos independentemente de como racionalizam ou organizam suas metas, e mesmo em ambientes anárquicos e com as mais diversas restrições humanas, materiais, econômicas, os atores criam iniciativas pessoais, a fim de transformá-las em ações que possam ser realizáveis (MONSMA, 2000).

A perspectiva do ator/agente é ampliada nas proposições da Teoria da Estruturação, uma crítica de Giddens (2003) à abordagem funcionalista, na qual a estrutura representa a padronização das relações sociais e dos fenômenos, e ao estruturalismo, o qual enfatiza que a estrutura é a padronização das relações no âmbito das interações sociais. Para Giddens, a estrutura são as regras expressas nas normas e códigos. Assim, então, a POA participa como elemento principal que auxilia na compreensão das ações efetivadas pelos atores/agentes, visando agir, garantir e preservar a reprodução social. Os elementos da Teoria da Estruturação expressam elementos normativos e funcionais que regulam a sociedade por meio de códigos de significação. Estes são expressos nos recursos impositivos e na manifestação das atividades práticas e cotidianas amparadas por alguma forma de racionalidade (a razão prática, na visão de Bourdieu), na reflexividade (capacidade de gerir a própria vida) e na intencionalidade indireta (efeitos são impremeditados) dos agentes (GIDDENS, 2003).

O fenômeno da cognoscitividade enfatizada por Giddens (2003) é a influência dos desafios captados pelo inconsciente e traduzidos em ações práticas na vida cotidiana dos atores por meio do senso prático, na concepção de Bourdieu (1996). Bourdieu (2001) enfatiza que o senso prático se torna em habitus, (uma segunda pele), opera por meio de um intrincado sistema de disposições duráveis e transferíveis, ao conferir o caráter gerador e organizador das práticas e representações sociais, associadas às condições da existência dos indivíduos. 0 habitus possui a capacidade prática, irredutível à razão teórica, ao se transformar em maneira de perceber, julgar e atribuir valores ao mundo percebido, que se expressam nas formas de agir, em termos corporais e materialmente. 


\section{Sustentabilidade e agricultura, um sonho a perseguir.}

O desenvolvimento sustentável, cujo conceito mais aceito foi aquele difundido pela Comissão Mundial sobre Meio Ambiente e Desenvolvimento (CMMAD), definindo no relatório "O nosso futuro comum" que "[...] O desenvolvimento sustentável é aquele que atende às necessidades do presente sem comprometer a possibilidade de as gerações futuras atenderem a suas próprias necessidades" (COMISSÃO MUNDIAL SOBRE MEIO AMBIENTE E DESENVOLVIMENTO, 1991, p. 46). E dessa forma, o desenvolvimento sustentável, nessa concepção é um conceito amplamente polissêmico, ambíguo e plástico e que se expressa por meio de inúmeras perspectivas e abordagens teóricas para compor a ideia de sustentabilidade. O entendimento múltiplo do conceito, se traduz no âmbito do ambientalismo, na economia verde, na ecologia profunda, na sustentabilidade forte e fraca e no ecossocialismo, etc., (BURSZTYN, PERSEGONA, 2008).

Mas, todo esse contorcionismo verborrágico interpreta a relação entre natureza e sociedade, quase sempre conflituosa, como um grande almoxarifado para uns e depósito lixo para outros, expresso nas distintas formas de contínuo saque dos bens e ativos naturais. Nessa concepção, o crescimento econômico visa objetivamente, por meio da produção e consumo de bens necessários e fúteis para atender às necessidades humanas de sobrevivência material e da preservação e elevação de status deve continuar ad infinintum. Essa perspectiva é dissecada pelo diretor e roteirista Jeff Gibbs ao descontruir a ideia de sustentabilidade e, do mesmo modo, apresenta a cooptação financeira de parte expressiva do movimento ambientalista, pela versão nociva do capitalismo, exibidos no documentário “Planeta dos Humanos" (GIBBS, 2020).

A polissemia do conceito facilita e se torna tentador e recorrente para o uso político e ideológico, quando expressa, pelo "politicamente correto do desenvolvimento sustentável, uma noção que pretende agregar o caráter interdisciplinar, interinstitucional e interageracional (BURSZTYN, BURSZTYN, 2012). Mas, ainda aguarda a chegada de uma acepção mais clarificadora e precisa. Mesmo assim, os autores defendem que o desenvolvimento sustentável se transformou na mais moderna das utopias, ao centralizar foco sobre as necessidades de proteção aos ativos e bens ambientais, como atributo essencial e basilar na busca de felicidade dos povos, na perenidade da vida e no compromisso do valor ético-moral com as gerações futuras e garantir a sobrevivência e o bem-estar. Este é um tema que adquiriu expressiva 
convergência na agenda política, acadêmica, governamental e empresarial ao expressar os sentidos do "politicamente correto" e esse argumento cobra responsabilidades dos agricultores na preservação, manutenção e uso e dos bens e ativos naturais.

Pode-se dizer que ainda é uma discussão e adoção de práticas inacabadas e inconclusas ao apresentar o dilema, especialmente pelo mundo interpretado pela economia, cada vez mais distante em que busca estabelecer a coexistência harmoniosa e de equilíbrio entre a necessidade de proteger e conservar os bens e ativos ambientais, com os imperativos de geração, manutenção e ampliação das atividades e riquezas econômicas, base da reprodução social das sociedades modernas. Essa abordagem de expressa de forma emblemática e serve para problematizar a importância e a expressão do cultivo da soja, tema a ser ampliado na seção seguinte.

\section{Por que o cultivo da soja é quase imbatível na busca duradora pelo dinheiro?}

O portfólio de rendas (aqui usado como lista de opções) foi utilizado como unidade de análise, limitada ao esclarecimento da relação dessa, dos estabelecimentos rurais pesquisados. Essa variável foi interpretada como espaço de produção e de reprodução das relações sociais e das estratégias de famílias e indivíduos, em que a esfera econômica é, via de regra, eleita e efetivada por meio de múltiplos recursos. Foi possível perceber a grande preocupação dos agricultores familiares com a condução de atividades agrícolas que ofereçam possibilidades de ganho econômico. Dessa forma, a preocupação ambiental foi secundarizada no rol das prioridades, na medida em que as explorações agrícolas obedecem ao padrão convencional de agricultura da Revolução Verde ${ }^{1}$, efetivada por meio intensivo do uso de agroquímicos e equipamentos agrícolas.

No caso da região estudada, a preponderância de plantio de soja é a expressão como carro chefe na geração de renda em 59,2\% dos empreendimentos rurais familiares, representando $36,8 \%$ da receita total dos estabelecimentos rurais investigados e $68 \%$ das receitas oriundas das atividades agrícolas. Nesse aspecto, é revelador o relato de um dos

\footnotetext{
${ }^{1}$ A Revolução Verde foi um programa de modernização agrícola financiada pela Fundação Rockfeller para ampliar a produção agrícola por meio do desenvolvimento de experiências no campo da genética vegetal para produzir sementes melhoradas e adaptadas ao clima e resistente a doenças e na introdução de técnicas tratos culturais modernos e eficientes (BRUM, 1983).
} 
agricultores: “[...] Olha, eu já tentei de tudo mas foi com a plantação da soja que tive o retorno mais fácil e seguro, quando a gente colhe bem, e me sobrou uns trocos pra melhorar, apesar de minha área não ser muito grande, mas compensei arrendando terra pra aumentar a área" (I. 08). Essa percepção da realidade foi capturada, de igual modo, pelo dirigente representante de uma cooperativa de comercialização de produtos da agricultura familiar, ao interpretar os fatores que emperram, ou mesmo bloqueiam, as tentativas de mudanças nos padrões produtivos na região do Alto Uruguai.

\begin{abstract}
A expansão da cultura de soja se tornou uma concorrente quase imbatível na introdução e consolidação de alternativas de produção na região do Alto Uruguai. Os agricultores detêm o conhecimento acumulado no cultivo da cultura de longa data. Existe um mercado razoavelmente garantido e, os agricultores preferem não se arriscar com alternativas que julgam arrojadas, sem comprovação de resultados econômicos. Além disso, os estabelecimentos cada vez mais tem escassez de mão de obra e são condicionados pelo sistema de crédito rural e pela assistência técnica em plantar a mesma coisa a que estão acostumados, e dessa forma, mantém e potencializa o padrão convencional de agricultura produtora de grãos, basicamente, de soja (I. 01).
\end{abstract}

Contudo, não parece haver nenhum ineditismo nessa constatação. Afinal, a sociedade moderna está sob a égide do capitalismo, inclusive na agricultura. Este é um processo que vem se revelando seletivo e se expõem, inclusive, na produção de soja, que amplia o volume de produção ano a ano (COMPANHIA NACIONAL DE ABASTECIMENTO, 2019). Embora seja recorrente na literatura das ciências sociais sobre o desenvolvimento rural, é presente a adoção de um viés crítico contundente das monoculturas, que, por vezes, representa uma visão anticapitalista da agricultura (NAVARRO, 2016). Contudo, no caso da importância e expansão da fronteira da soja, ela se constitui na perspectiva dos produtos que "tenham comércio" razoavelmente assegurado, como foi lembrado pelo dirigente entrevistado. Além disso, o cultivo da leguminosa representa o pacote tecnológico, amplamente absorvido pelos agricultores familiares e focado fortemente no produtivismo que viabiliza o desenvolvimento agrícola (NAVARRO, 2001), consolidado pela agricultura tradicional, em que a demanda ambiental não está, a priori, embutida.

O cultivo da soja é um fator que pode ser interpretado como símbolo e expressão emblemática do modelo de modernização e mercantilização da agricultura na região. 0 modelo introduziu transformações culturais nos comportamentos sociais, incutiram uma racionalidade instrumental nitidamente capitalista, especialmente por meio da especialização, espacialização e territorialização da commoditie (CONTERATO, 2008). 
Esses fatores representam a perda de autonomia dos agricultores, grande parte devido à necessidade da adoção de inovações tecnológicas por meio da exigência de progresso técnico contínuo. E ainda, é possível inferir que os agricultores familiares foram e continuam sendo cooptados ou "capturados" pela opção, compulsão ou mesmo a "obrigatoriedade" das agroindústrias, dos agentes financeiros, da assistência técnica e pela via dos financiamentos disponibilizados pelo crédito rural oficial. A assistência técnica nessa modalidade se transformou em apenas uma modalidade burocrática e procedimental da imposição legal na obtenção do crédito rural (TOLEDO, 2009). As opções adotadas priorizam as opções comerciais e tradicionais "mais seguras", na expectativa e esperança de reduzir os riscos (do sistema de crédito), a fim de "produzir" excedentes capazes de garantir reprodução social e material.

Essa opção sacrifica, inclusive, a produção de alimentos básicos para a manutenção das famílias, que passam a ser supridos pelas receitas oriundas dos cultivos comerciais, mercantilizando, inclusive, a sobrevivência das famílias (BERNSTEIN, 2011). Gazolla (2004), encontrou essa evidência ao estudar as influências do processo de "sojicização" dos agricultores familiares da região missioneira do Rio Grande do Sul por meio da fragilização da produção para o autoconsumo alimentar das famílias rurais. O fenômeno se "[...] desenvolve com a compra direta dos alimentos pelos agricultores de feirantes, fruteiros e vendedores ambulantes de gêneros alimentícios que percorrem as comunidades [...]." (GAZOLLA, 2004, p. 131). Dos mais de 63 milhões de hectares de plantio, previstos para a safra 2019/2020, a área plantada de soja representou $55,5 \%$ do total e, na estimativa de produção total no Brasil, $48,3 \%$ das 235,3 milhões de toneladas previstas para serem colhidas no período (COMPANHIA NACIONAL DE ABASTECIMENTO, 2019). A cultura tem uma importância vital na irrigação financeira de centenas de municípios na economia brasileira, mas indiscutivelmente sedimenta a agricultura de larga escala e aprofunda os efeitos da seletividade e diferenciação entre os agricultores e entre as regiões rurais.

Os dados da Tabela 1, mostram as informações do Censo Agropecuário de 2006, separando os dados da produção de soja oriunda agricultura familiar e da não familiar. Os dados mostram que $14 \%$ da soja brasileira produzida à época foi gerada nos domínios da agricultura familiar, sendo que a região Sul representou 85,18\% dessa produção.

Na projeção efetuada para 2019, utilizando como estimativa o mesmo percentual de 14\% encontrado nos dados do Censo de 2006, já que o Censo Agropecuário de 2017 agrupou todas as informações de produção, não separando o que é familiar e não familiar. A região Sul 
reduziu o patamar de $85,18 \%$ para $82,05 \%$ do total da produção. No entanto, houve aumento do cultivo da leguminosa nas demais regiões brasileiras. Na região Norte a produção passou de 0,57\% para 1,98\% da produção total da agricultura, Nordeste de $0,54 \%$ para $0,64 \%$, Sudeste de 2,9\% para 3,45\% e na região Centro-Oeste de 10,8\% para 11,88\%. Essa "virtude" expansionista preocupa pelos impactos ambientais causados pelas mudanças no uso da terra pela via do desmatamento e pelo desenraizamento sistemático de populações tradicionais para dar lugar às explorações da monocultura em larga escala.

Tabela 1 - Soja produzida na agricultura familiar e não familiar.

\begin{tabular}{l|r|r|r|r|r|r|r|r}
\hline Unidade & \multicolumn{4}{|c|}{ Tipo de agricultura - 2006 } & \multicolumn{3}{c}{ Participação AF 2019 - Projeção* } \\
\hline Territorial & \multicolumn{1}{|c|}{ Total } & $\begin{array}{c}\text { AF - Lei no } \\
11.326\end{array}$ & \multicolumn{1}{c}{$\%$} & Não familiar & \% AF & Safra 2019 & $\begin{array}{c}\text { Safra AF } \\
2019\end{array}$ & $\begin{array}{c}\text { \% } \\
\text { região }\end{array}$ \\
\hline Norte & 767.185 & 36.803 & 0,57 & 730.383 & 4,8 & 5.953 .017 & 285.745 & 1,98 \\
\hline Nordeste & 3.714 .806 & 35.157 & 0,54 & 3.679 .649 & 0,9 & 10.345 .207 & 93.107 & 0,64 \\
\hline Sudeste & 3.047 .571 & 187.651 & 2,9 & 2.859 .921 & 6,2 & 8.040 .400 & 498.505 & 3,45 \\
\hline Sul & 17.420 .110 & 5.506 .822 & 85,18 & 11.913 .288 & 31,6 & 37.502 .900 & 11.850 .916 & 82,05 \\
\hline $\begin{array}{l}\text { Centro- } \\
\text { Oeste }\end{array}$ & 21.246 .169 & 698.306 & 10,8 & 20.547 .864 & 3,3 & 51.981 .908 & 1.715 .403 & 11,88 \\
\hline Brasil - Total & 46.195 .843 & 6.464 .739 & 100 & 39.731 .104 & 14,0 & 113.823 .432 & 14.443 .676 & 100,00 \\
\hline
\end{tabular}

Fontes: Censo Agropecuário 2006, (IBGE, 2006) e CONAB (2019). Toledo (2017).

* Projeção com base no Acompanhamento da Safra Brasileira - Grãos. Sétimo Levantamento. Abril 2019.

Elaboração: Dieese (2017). Atualizado.

A ideia de "concorrente imbatível", lembrada pelo entrevistado da cooperativa, vem no escopo associado à expansão da especialização reproduzida, por meio da perícia técnica e produtiva dos agricultores ao manejar os recursos da crescente modalidade de cientifização da agricultura (PLOEG, 1990). Crescimento disponibilizado pelo acesso aos insumos, maquinário e produtos químicos e pela potencialização produtiva das sementes geneticamente melhoradas e/ou modificadas. O autor ainda enfatiza que o contínuo processo de externalização produtiva (necessidades de crédito rural assistência técnica, aquisição de insumos, máquina e equipamentos) precipitou e sedimentou a contínua perda de autonomia dos agricultores na busca do contínuo ingresso de dinheiro ao estabelecimento.

As bases econômicas da agricultura estiveram e ainda estão assentadas na necessidade de integração aos mercados, como estratégia para gerar excedentes econômicos passíveis de acumulação privada e de reprodução social. Essa necessidade foi traduzida substancialmente na figura da monetarização, sob a predominância do auto interesse, tema denunciado vigorosamente por Polanyi (2000) como uma das fontes deletérias dos males às sociedades 
modernas. No entanto, os economistas não são cientistas que pesquisam e estudam as leis naturais, eles estudam os mecanismos baseados em práticas e comportamentos sociais, estabelecidos a partir do poder político entre os diferentes agentes econômicos (DOWBOR, 2007).

Outro aspecto a lembrar é a sistêmica bancarização da esfera econômica por meio da contratação contínua de financiamento de crédito rural, sem o qual a maioria dos agricultores ficaria impedida de promover a viabilização da próxima safra. A simples oferta de crédito, não raro, fragiliza ainda mais a situação econômica dos agricultores, expressa pelo endividamento crônico, remendado periodicamente por meio de renegociações de dívidas rurais, pois “[...] esta forma de agricultura tenha desenvolvido uma necessidade crônica de crédito na impossibilidade de refinanciamento interno das unidades de produção" (NIEDERLE, 2007, p. 99). A dependência permanente de crédito denuncia a fragilidade estrutural dos agricultores para gerar capacidade de renda extraordinária somente com os mecanismos de mercado, que não podem ser aplicados integralmente à agricultura sem o aporte de proteção de políticas públicas.

O trabalho de Toledo (2009) realizado em Salvador das Missões (RS) é sintomático ao anotar que os agricultores familiares buscam continuamente formas de ampliar o acesso à recursos financeiros. Essa estratégia visa atender às necessidades econômicas de capital de giro dos estabelecimentos rurais e, por vezes, para cobrir demandas emergenciais e despesas diversas. A necessidade contínua de dinheiro efetivada por meio de uma atividade agropecuária que ofereça essa possibilidade decompõe os modos tradicionais de vida dos agricultores, acossados por novas necessidades. Contudo, parte delas nem são de ordem estritamente produtiva do estabelecimento rural (o acesso aos bens de consumo, por exemplo). Porém, essas demandas, via de regra, não são suportadas pelas atividades agropecuárias desenvolvidas. Esse processo se sedimenta na medida em que os agricultores familiares são apenas tomadores de preço, e não formadores de preço.

Moscovici (1990) menciona que o dinheiro é a grande metáfora produzida pelas sociedades modernas. Isso ocorre na medida em que vincula, intercede e possibilita aos indivíduos o instrumento basilar capaz de construir a possibilidade e uma nova realidade de relações sociais e de acesso a bens materiais que revelam status social e aceitação por meio de:

[...] imagens e signos que, a projeção das simples relações nos objetos particulares é 
uma realização do espírito; quando o espírito se encarna nos objetos, eles se tornam um veículo para o espírito e lhe atribuem uma atividade mais viva e mais ampla. A capacidade de construir tais objetos simplesmente alcança seu maior triunfo no dinheiro. O dinheiro representa a interação mais pura e sua forma mais pura; é uma coisa individual cujo significado essencial é ir além das individualidades. O dinheiro é então a expressão adequada da relação do homem com o mundo, que só podemos apreender em exemplos concretos e particulares, mas que só podemos realmente conceber quando o singular se torna encarnação do processo mútuo vivo que entrelaça todas as singularidades e, sob esta forma cria a realidade (MOSCOVICl, 1990, p. 287).

Isto é fato, os agricultores familiares estão sendo continuamente submetidos e governados pela competição intercapitalista, visando a melhor posição para a realização das trocas (via mercado) das suas mercadorias, o que lhes permite gerar possibilidades de obter lucros e, por consequência, se possível, acumular. Além disso, a pequena "margem de manobra" dos agricultores dá pouco espaço para "aventuras" produtivas exóticas para além do tradicional e convencional em termos gerais, quando o que está em jogo é o futuro do estabelecimento e da própria manutenção e reprodução da família. Dessa forma, não é de admirar que os agricultores familiares tendam a reagir e agir de forma conservadora, pois há muita a perder.

A decisão da ação converge como um conjunto de habilidades desenvolvidas, conhecimentos e práticas historicamente acumuladas, conjugadas com os recursos alocados, que permitam um "cálculo", ainda que intuitivo, de um mínimo de possibilidade de sucesso. Esta é a expressão ontológica do agente e da perspectiva orientada ao ator dos agricultores, decidindo e trabalhando pelos melhores resultados. Contudo, mesmo considerando essas perspectivas, sempre haverá margem para resultados inesperados e consequências não premeditadas das ações (GIDDENS, 2003), que podem ser negativas na medida em que os atores não possuam o domínio e o controle completo de todas as informações.

\subsection{Esperanças (in)certas, o rentismo da terra e de novo o "ornitorrinco social"?}

A Tabela 2 aponta os motivos interpretados pela visão dos agricultores familiares, como justificativas plausíveis para abandonar as atividades agrícolas. Da amostra, 44,4\% responderam que vão permanecer, $22,2 \%$ dizem que podem abandonar por culpa dos preços agrícolas inadequados (que não cobrem custos e nem remunera as atividades). Isso faz sentido, na medida em que os preços dos produtos agrícolas trazem embutida a ideia de valorização e 
remuneração do trabalho, do investimento, das melhorias, o retorno do capital investido e o "salário" dos agricultores. Dessa forma, a preocupação com os preços agrícolas afeta as possibilidades de geração da renda extraordinária.

Dever ser ressaltado que a estreita "margem de manobra" na geração de excedentes econômicos, situação em que operam a maioria dos agricultores, intensifica a base preponderante e seletiva de acumulação privada nas regiões rurais. Os 4,5 milhões de estabelecimentos geraram $13 \%$ do valor bruto da produção e necessitam complementar a renda familiar com ingressos oriundos de outras fontes (trabalho em outras propriedades ou em outros setores, programas sociais de renda mínima, aposentadorias, etc.) para que possam permanecer no campo. Na outra ponta, 500 mil estabelecimentos respondem por $87 \%$ do valor bruto da produção agropecuária brasileira, sacramentando a desigualdade produtiva e social no setor agropecuário (OLIVEIRA, VIEIRA FILHO, 2019).

Tabela 2 - Razões apontadas pelos agricultores entrevistados para o abandono das atividades agrícolas (Ano agrícola 2018/2019)

\begin{tabular}{l|c|c|c}
\hline Razões & Frequência & $\%$ & $\%$ acumulado \\
\hline Responderam que vão permanecer & 24 & 44,4 & 44,4 \\
\hline Preços agrícolas inadequados & 12 & 22,2 & 66,6 \\
\hline Não tem mão de obra & 10 & 18,5 & 85,1 \\
\hline Rigor da legislação ambiental & 4 & 7,4 & 92,5 \\
\hline Escala de produção inadequada & 2 & 3,7 & 96,2 \\
\hline Insegurança no meio rural & 2 & 3,7 & 100 \\
\hline Total & 54 & 100,0 & ---- \\
\hline
\end{tabular}

Fonte: Dados de pesquisa (2019).

Com relação à disponibilidade de mão de obra, 18,5\% dos agricultores entrevistados apontaram como podendo ser uma das razões para abandonar a atividade agrícola. Este fator foi lembrado porque a (in)disponibilidade dela compromete a capacidade produtiva dos estabelecimentos. O rigor da legislação ambiental ficou em quarto lugar nas razões para um possível abandono, com 7,4\% da amostra. Essa informação revela que o suposto "rigor" da legislação, justificativa veiculada pelos representantes dos agricultores (familiares e não familiares) para apontar a legislação ambiental como um fator que dificulta a vida dos agricultores, é inadequado e relativo, já que não é amplamente validada pelos agricultores familiares.

Da amostra, apenas 3,7\% dos agricultores disseram que a escala de produção inadequada e a insegurança no meio rural são motivos de abandono. Verificou-se que é pouco COLÓQUIO - Revista do Desenvolvimento Regional - Faccat - Taquara/RS - v. 17, n. 4, out./dez. 2020 
provável que agricultores com baixa capacidade de gerar excedentes possam atentar prioritariamente para as demandas de conservação e proteção de ativos e bens naturais. Uma alternativa possível, inclusive, de geração de renda para esse estrato de agricultores familiares, poderia ser a adoção de políticas de pagamento por serviços ambientais (PSA), agregados ao processo produtivo. Essa opção deve ser direcionada, preferencialmente para os agricultores familiares em situação de fragilidade institucional, que de alguma forma estão cumprindo a legislação ambiental. Ou seja, os percentuais mínimos de áreas de preservação permanente $\left(A P P^{2}\right)$ e reserva legal $\left(R L^{3}\right)$ exigidos pela legislação ambiental, tornando-se um mecanismo auxiliar de geração de renda no estabelecimento rural. Essa perspectiva foi lembrada pelo representante da cooperativa de produção.

O problema da conservação e a proteção dos recursos naturais não deve ser uma atribuição exclusiva dos agricultores familiares. Contudo, a legislação ambiental, tradicionalmente trata os agricultores, grosso modo, como potencialmente infratores. Entretanto, pouco foi feito nos aspectos ligados à educação, e na oferta de alternativas que valorizem e remunerem os agricultores pelo cuidado desses recursos, afinal, essa é uma tarefa que beneficia toda sociedade, mas que ainda reluta em compreender e remunerar os agricultores por isso. Estamos ainda muito longe desse patamar (I. 01).

De qualquer modo, a saída apontada indica ser a utilização de incentivos por meio de instrumentos econômicos pela via da monetarização dos serviços ambientais pela via dos PSA, mas essa possibilidade é fonte de inúmeras controvérsias. A contestação se dá pela denúncia veemente do processo de mercantilização dos bens e serviços da natureza realizada por meio da valoração econômica (MARTINS, 2004, SCHMIED-KOWARZIK, 2019). A crítica é direcionada, ao tomar como certo, à ampliação das influências do capitalismo, em que a natureza se converteu em um conjunto produtivo de objetos, procedimentos do trabalho e os processos ecológicos foram transformados e participam da formação de valor e da produção de mais-

\footnotetext{
2 São consideradas áreas de preservação permanente (APP), as faixas marginais dos cursos de água, que variam de 30 a 500 metros, as áreas no entorno dos reservatórios d'água artificiais, de barramento ou represamento de cursos d'água naturais, as áreas no entorno das nascentes e dos olhos d'água perenes (raio mínimo de 50 metros), as encostas ou partes destas com declividade superior a $45^{\circ}$, equivalente a 100 na linha de maior declive; as restingas, fixadoras de dunas ou estabilizadoras de mangues; os manguezais, as bordas dos tabuleiros ou chapadas, até a linha de ruptura do relevo, em faixa nunca inferior a 100 metros em projeções horizontais; no topo de morros, montes, montanhas e serras, com altura mínima de 100 metros e inclinação média maior que $25^{\circ}$, as áreas em altitude superior a 1.800 metros, em veredas, a faixa marginal, com largura mínima de 50 metros, a partir do espaço permanentemente brejoso e encharcado (Lei no 12.651/2012, BRASIL, 2012).
}

${ }^{3}$ São consideradas áreas de reserva legal ( $\mathrm{RL}$ ), na Amazônia Legal: a) 80\% no imóvel situado em área de florestas; b) $35 \%$ no imóvel situado em área de cerrado; c) $20 \%$ (vinte por cento), no imóvel situado em área de campos gerais; 20\% para os estabelecimentos rurais das demais regiões: 20\%. (Lei no 12.651/2012, BRASIL, 2012). 
valia. Dessa forma, a natureza estaria sendo absorvida no processo de reprodução do capital (LEFF, 1986, BIGGS, 2020).

Nas áreas pesquisadas (os municípios de Barão de Cotegipe, Sertão e Viadutos), 83,3\% da área dos estabelecimentos é inferior a 50 hectares. Esse fator estrutural representa um sério entrave para as exigências da moderna produção, que demanda escala comercial, exigidos pelo cultivo da soja e milho, como condição e capacidade para gerar viabilidade econômica, que tecnicamente está excluindo os estabelecimentos com áreas reduzidas. Contudo, parte dessa dificuldade está sendo remediada por alguns agricultores, pela adoção das estratégias de arrendamento das terras de outros agricultores, que, por opção ou por impossibilidades várias não cultivam suas áreas. O pagamento do arrendamento, conforme informações colhidas pela pesquisa, equivalente a 20 a 25 sacas de soja por hectare, que ao preço de mercado vigente, segundo dados coletado, representa 9,54\% dos custos fixos para os arrendatários na condução das lavouras.

Um estudo conduzido por Guedes, Cazella e Capellesso (2018) apontaram que a opção pelo arrendamento ocorre em situações em que o fato da maioria dos estabelecimentos rurais não apresentar sucessores em suas unidades produtivas ou, ainda, pela carência ou inadequação da infraestrutura de produção. Por outro lado, de alguma forma, eles mantém o vínculo com a agricultura por meio de pequenos cultivos, utilizados para subsistência, mantendo a importância de se obter um rendimento com menor incerteza frente ao clima e sem a necessidade de empregar mão de obra, já que a maioria desses proprietários são idosos.

Confirmando a importância do arrendamento, os dados da Tabela 3 demonstram que 20,4\% dos entrevistados arrendaram 355 (ha) de terceiros, (cerca de 22,69\% do total das terras próprias dos agricultores investigados). Essa opção foi utilizada para ampliar a área de exploração, especialmente das culturas que exigem escala de produção (soja e milho). Por outro lado, 35,2\% dos agricultores familiares arrendaram 460 (ha) para outros, cerca $29,40 \%$ das áreas próprias da investigação.

Essa opção representou 4,19\% (média de R\$ 28.148,00 no ano agrícola 2018/2019) do total de ingresso da receita bruta dos estabelecimentos. A entrevista confirmou que "[...] Nós não temos mais mão de obra, os piás já se foram prá cidade em busca de emprego, dá mais e é mais fácil. A terra é pequena, não dá prá acomodar todo mundo, e nós estamos com idade avançada, assim decidimos arrendar, é mais seguro, complementa a aposentadoria prá ir vivendo" (I. 05). Da amostra, 83,3\% possui idade acima de 55 anos, 31,5\% informaram não ter 
nenhum sucessor previsto para assumir as atividades dos estabelecimentos rurais e $33,3 \%$ não tem certeza de quem vai tomar conta deles.

Tabela 3 - Áreas alocadas para arrendamento (Ano agrícola 2018/2019).

\begin{tabular}{l|c|r|c|c|c|c}
\hline \multicolumn{4}{c|}{ De terceiros } & \multicolumn{3}{|c}{ Para terceiros } \\
\hline Arrendamento & Frequência & $\%$ & Área arrendada & Frequência & $\%$ & Área arrendada \\
\cline { 1 - 1 } Não & 43 & 79,6 & (ha) & 35 & 64,8 & (ha) \\
\hline Sim & 11 & 20,4 & 355 & 19 & 35,2 & 460 \\
\hline Total & 54 & 100,0 & & 54 & 100 & \\
\hline
\end{tabular}

Fonte: Dados da pesquisa (2019).

Significa afirmar, que a problemática de sucessão dos estabelecimentos rurais é uma dura realidade, sem que, no entanto, exista uma estratégia elaboradas pelas famílias ou pelo Estado, articulada para enfrentar o fenômeno. Ao disponibilizar as áreas para o arrendamento, por opção de ingresso de renda ou mesmo por impossibilidade estrutural de exploração produtiva, os agricultores familiares agregam mais um componente ao leque identitário, ao se transformarem em rentistas da terra. Essa opção amplia a problemática em caracterizar adequadamente o que seja o "agricultor familiar", o "ornitorrinco social" que teimosamente sobrevive no interior do sistema capitalista (ABRAMOVAY, 2012). É um personagem híbrido “[...] acumulando nele mesmo uma tríplice identidade: proprietário fundiário, empresário privado e trabalhador". (JEAN, 1994, p. 53).

O arrendamento está se tornando uma alternativa de ingresso de renda para os agricultores familiares com pouco terra, ou com deficiências de mão de obra, e para aqueles que não querem ou que não apresentam condições estruturais ou recursos favoráveis para imobilizar capital nesse meio de produção. Além disso, o arrendamento não induz o arrendatário a elaborar estratégias de uso sustentável dos bens e ativos ambientais, tendendo a agravar a exploração predatória da terra arrendada. Esse fator torna difícil, quando não impossível, adotar estratégias que visam a sustentabilidade no uso dos ativos que beneficiem o proprietário da terra. A lógica do arrendamento encontra apoio na perspectiva de relativização da importância da terra, como um fator principal no cômputo Produtividade Total dos Fatores (PTF) da produção agrícola. O fator mais importante, nas últimas décadas, tem sido a alocação em investimentos em tecnologia agrícola de produção (SOUZA et al., (2012), como estratégia de aumentar a produtividade da terra e do trabalho.

A Tabela 4 apresenta o portfólio de rendas que compuseram a receita bruta dos 54 
estabelecimentos rurais investigados, tendo por base o total de ingressos para cada uma das modalidades auferidas no ano agrícola 2018/2019. O ingresso pela via do arrendamento representou 4,12\% das receitas (média anual de $\mathrm{R} \$ 28.148,00$ ), os valores auferidos com os produtos utilizados para o autoconsumo da família significaram 1,90\% (média de $\mathrm{R} \$ 4.331,85$ anuais). As atividades com bases florestais (plantio e venda de florestas comerciais - poupança florestal) rendeu 0,82\% (média de $\mathrm{R} \$$ 9.159,00) e os valores oriundos das atividades agrícolas foram de 54,93\% (média de $\mathrm{R} \$$ 140.836,04 anuais). As atividades de pecuária (suínos, leite, bovinos de corte) auferiram 27,50\% das receitas totais (média $\mathrm{R} \$ \mathbf{1 0 5 . 7 6 8 , 0 6}$ anuais), a indústria de transformação caseira foi de 0,89\% de ingressos, (média de $R \$$ 4.740,65 anuais) e as aposentadorias rurais e pensões, representaram 9,84\% do ingresso anual, (média de R\$ $25.759,36$ anuais).

Tabela 4 - Composição da Receita Bruta Anual dos estabelecimentos rurais pesquisados

\begin{tabular}{l|c|r|r|r}
\hline \multirow{2}{*}{ Tipo de receita } & \multirow{2}{*}{ Estabelecimentos } & \multicolumn{2}{|c}{ Receita Bruta Anual (em R\$) } \\
\cline { 3 - 5 } & & Total & \multicolumn{1}{c}{$\%$} & Média \\
\hline Arrendamento de terras & 18 & $506.664,00$ & 4,12 & $28.148,00$ \\
\hline Produtos para autoconsumo & 54 & $233.920,00$ & 1,90 & $4.331,85$ \\
\hline Atividades florestais & 11 & $100.750,00$ & 0,82 & $9.159,09$ \\
\hline Atividades agrícolas & 48 & $6.760 .130,00$ & 54,93 & $140.836,04$ \\
\hline Atividades da pecuária & 32 & $3.384 .578,00$ & 27,50 & $105.768,06$ \\
\hline Aposentadorias e pensões & 47 & $1.210 .690,00$ & 9,84 & $25.759,36$ \\
\hline Indústria caseira & 23 & $109.035,00$ & 0,89 & $4.740,65$ \\
\hline Total (Amostra) & 54 & $12.305 .767,00$ & 100,0 & - \\
\hline
\end{tabular}

Fonte: Dados de pesquisa (2019). (Ano Agrícola 2018/2019).

Cabe ainda um comentário adicional sobre as três atividades que representaram as maiores receitas dos estabelecimentos: as atividades agrícolas (especialmente, de soja e milho), aquelas oriundas da pecuária (atividades com a produção de leite, suínos e bovinos de corte) e as aposentadorias rurais e pensões (Tabela 4). O conjunto agregado desses ingressos representaram 92,27\% do total da receita bruta dos estabelecimentos. Os dados da pesquisa revelaram, que as receitas originárias da agricultura são expressivas, desvenda de igual modo, a profissionalização e especialização no manejo das culturas soja e milho. Do mesmo modo, os rendimentos oriundos das aposentadorias e pensões, são extremamente importantes para os estabelecimentos rurais que possuem receitas brutas inferiores a $R \$ 50.000,00$ anuais. Representaram de 57,8\%, (até $\mathrm{R} \$ \mathbf{5 0 . 0 0 0}$ ) e de $29,6 \%$ da receita bruta anual inferior a $\mathrm{R} \$$ $100.000,00$ respectivamente. 
Além disso, os estabelecimentos que tiveram resultados negativos, o ingresso das aposentadorias e pensões, garantiram, grosso modo, o sustento da família, embora, não garanta a manutenção produtiva indefinidamente. Merece destaque a baixa expressão dos investimentos na área florestal $(0,82 \%)$ que poderia indicar alguma preocupação com a esfera ambiental, no tocante a recuperação da cobertura vegetal, pois os estabelecimentos apresentaram passivos ambientais, $38,9 \%$ possuem $\mathrm{RL}$ a menos do que previsto na legislação e 29,6\% tem débitos com APP. A opção dos investimentos na área ambiental foi enquadrada no segmento denominada de "poupança florestal", ou seja, o plantio e cultivo de espécies arbóreas para fins de exploração comercial (acácia negra - Acacia decurrens, pinus -Pinus sp, ou eucalipto - Eucalyptus sp).

Ainda, o estudo constatou que $83,3 \%$ dos estabelecimentos declararam ingresso de recursos monetários de aposentadorias e pensões, contra $16,7 \%$ que não têm esse tipo de renda. Este ingresso torna-se crucial na medida em que inúmeras famílias auferiram o valor agregado anual inferior a $\mathrm{R} \$ 25.000,00$, retratando, portanto, condições de pobreza, de dependência de transferências públicas para sobrevivência, o que para Buainain e Garcia (2013) apenas retarda a exclusão no curto prazo.

\section{A insustentável leveza da preocupação ambiental}

Com relação a realização de investimentos, os dados da Tabela 5 indicaram que 72,2\% da amostra não realizou nenhum investimento em recuperação de passivos ambientais (áreas degradadas, ou áreas de $R L, A P P$ ) e manutenção de bens naturais (nascentes, RL, APP), mas $24,1 \%$ informaram ter realizado, $3,7 \%$ não souberam ou não responderam. Contudo, a "preocupação" dos agricultores familiares com a demanda ambiental e que afirmaram ter realizado investimentos, irremediavelmente se apresentaram conjugados com algum aceno e possibilidades de retorno econômico, por meio da atividade ambiental financiada (a poupança florestal).

Outra informação da Tabela 5 mostra-se que os estabelecimentos, segundo os agricultores familiares revelaram, foram multados em $74,1 \%$ da amostra (sendo $16,7 \%$ por desmatamento em APP, 5,6\% em RL e 3,7\% por lançamento de dejetos) e $25,9 \%$ responderam que não. Quando se faz o cruzamento das informações dos "investimentos" realizados com os estabelecimentos multados, há uma notável correspondência. Os investimentos podem ter sido 
realizados devido a coerção das multas emitidas pela fiscalização ambiental, essa informação demonstra pelas vias tortas, que a legislação cumpriu sua função, ou seja, a reparação dos danos praticados.

Tabela 5 - Investimentos em recuperação de passivos ambientais (áreas degradadas, RL e APP) e manutenção de bens naturais (nascentes, RL e APP).

\begin{tabular}{l|r|r|c|c}
\hline $\begin{array}{l}\text { Investimentos em área } \\
\text { ambiental }\end{array}$ & Frequência & $\%$ & $\begin{array}{c}\text { Estabelecimentos multados } \\
\text { por infração ambiental }\end{array}$ & $\%$ \\
\hline Não & 39 & 72,2 & 40 & 74,1 \\
\hline Sim & 13 & 24,1 & 14 & 25,9 \\
\hline Não sabe/não respondeu & 2 & 3,7 & - & \\
\hline Total & 54 & 100,0 & 54 & 100,0 \\
\hline
\end{tabular}

Fonte: Dados de pesquisa (2019). (Ano agrícola 2018/2019).

A fim de clarificar a extensão com a "preocupação ambiental", buscou-se localizar em que modalidades os agricultores familiares alocaram os recursos dos investimentos na área ambiental. Os dados da Tabela 6 mostram que houve 5,5\% da amostra alocou recursos na recuperação de $\mathrm{APP}, 3,7 \%$ os recursos foram destinados para a recuperação de $\mathrm{RL} 1,9 \%$ aportou na recuperação de nascentes. Somando os estratos que alocaram recursos nesses investimentos, acumularam $11,1 \%$ da amostra. Outros $13 \%$ fizeram investimentos em poupança florestal, que usam áreas não adequadas para explorações agrícolas confirmando a suspeita de que os investimentos na modalidade florestal, buscam possibilidades de retorno econômico por meio da exploração de madeira, comercialização de lenha ou outros produtos. Contudo, $72,2 \%$ da amostra informou não ter realizado nenhum investimento, $3,7 \%$ não soube ou não respondeu.

Tabela 6 - Modalidades de investimentos realizados na área ambiental.

\begin{tabular}{l|r|r|r}
\hline Modalidades & Frequência & \multicolumn{1}{|c|}{$\begin{array}{c}\% \\
\text { acumulado }\end{array}$} \\
\hline Recuperação de área de preservação permanente (APP) & 3 & 5,5 & 5,5 \\
\hline Recuperação de reserva legal (RL) & 2 & 3,7 & 9,2 \\
\hline Recuperação de nascentes & 1 & 1,9 & 11,1 \\
\hline Poupança florestal (pinus, eucalipto, acácia) & 7 & 13,0 & 24,1 \\
\hline Nenhum investimento realizado & 39 & 72,2 & 96,3 \\
\hline Não sabe ou não respondeu & 2 & 3,7 & 100,0 \\
\hline Total & 54 & 100 & ---- \\
\hline
\end{tabular}

Fonte: Dados de pesquisa (2019). (Ano agrícola 2018/2019)

Essas informações são importantes para compreender o uso do solo dos 
estabelecimentos, que traduzem as necessidades produtivas e econômicas dos agricultores familiares. Contudo, um fato parece sedimentar o centro da problemática, a urgência de gerar excedentes econômicos como estratégia de sobrevivência é para uma minoria que reúne as condições adequadas.

A agricultura, nos moldes atuais, está se transformando em uma atividade econômica, competitiva e concorrencial nos moldes schumpeterianos. Embora reconheça que a lógica econômica não possa ser aplicada ipsis litteris nas atividades agropecuárias sem as devidas ressalvas. São mercados imperfeitos, em que os riscos das atividades, no caso brasileiro, são nitidamente privados e o apoio do Estado se efetua de forma insuficiente e pontual por meio de programas de curto prazo. Essa opção faz com que o segmento se torne cada vez mais seletivo e excludente, especialmente para os mais fragilizados, para aos quais a estratégia adotada pelos distintos governos parece ser a de ganhar tempo (ALVES, ROCHA, 2010). Isso, diante do risco potencialmente forte de exclusão, na medida em que as condições estruturais da agricultura e das regiões rurais ainda permanece em busca de soluções.

Dessa forma, a dimensão econômica está se tornando cada vez mais majoritária. Essa concepção é anotada claramente por um dos dirigentes de uma cooperativa de comercialização. $\mathrm{O}$ dirigente enfatizou a contínua negação em compreender e ampliar o conhecimento sobre as particularidades e necessidades, radicalmente transformadas dos agricultores e do meio rural.

\footnotetext{
A negligência ou a dificuldade de lidar com as necessidades econômicas e produtivas dos agricultores por parte das organizações da agricultura familiar, está comprometendo negativamente, inclusive, as estruturas de transformação e comercialização dos produtos para o mercado que ainda existem. Estamos perdendo o debate político da relação duramente defendida entre as demandas da sustentabilidade, e sua possível vocação intrínseca com a agricultura familiar como produtora de alimentos saudáveis, seguros e sustentáveis. 0 espaço está paulatinamente está sendo ocupado por organizações e grandes grupos empresariais, inclusive, estrangeiros. Além disso, a preocupação com a proteção dos recursos naturais, constantemente cobrada dos agricultores familiares, fica longe da realidade, sem educação ambiental, sem investimentos públicos consistentes e, a garantia de remuneração pela produção diferenciada de alimentos e pelo cuidado à natureza, que a meu ver não virão. E a conjuntura política e econômica do país no curto e médio prazo tendem a ficar mais complicada para agricultura familiar (I. 01).
}

A possibilidade expressa acima exige uma nova abordagem a respeito do papel do Estado no financiamento das necessidades da agricultura, e, mais recentemente, das demandas de cuidados e prudência no uso dos bens e ativos ambientais. Em anos recentes, o que vem sendo constatado é o paulatino abandono do apoio estrutural do Estado às necessidades rurais. 
Gasques e Bastos (2014) apontaram que entre os anos de 1990 e 2009 os gastos públicos destinados às "funções rurais" (agricultura e organização agrária) foram reduzidos em mais de $\mathrm{R} \$ 100$ bilhões, pela via do orçamento geral da União. O patamar chegou a ser de até $11 \%$ na metade da década de 1980 e passou para menos de 1\% em 2018, (AUDITORIA CIDADÃ DA DÍVIDA, 2018).

Os dados expressos na Tabela 7 se referem às informações tabuladas pelo Censo Agropecuário do IBGE de 2017 (IBGE, 2017), referente a todos os estabelecimentos dos municípios investigados. As informações mostram que as práticas agronômicas adotadas pelos agricultores podem aludir alguma "preocupação" ambiental na condução produtiva dos empreendimentos. O uso do plantio em curva de nível (ou terraços) foi de 0,29\% em Barão de Cotegipe, 1,36\% em Sertão e 5,96\% em Viadutos. Essa técnica admite a necessidade de algum investimento com máquinas e equipamentos para sua implantação, mas está sendo substituída pela modalidade do plantio direto (Tabela 7).

Tabela 7 - Número de estabelecimentos e práticas agrícolas adotadas.

\begin{tabular}{|c|c|c|c|c|c|c|c|c|c|c|c|c|}
\hline \multicolumn{13}{|c|}{ Modalidades (\%). } \\
\hline Municípios & 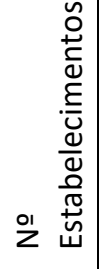 & 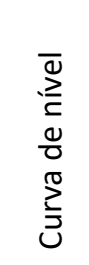 & 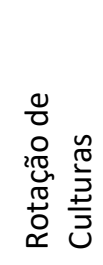 & 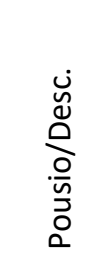 & 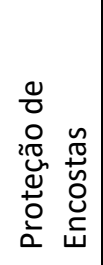 & 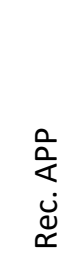 & 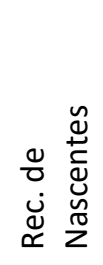 & 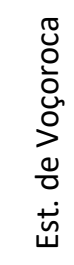 & 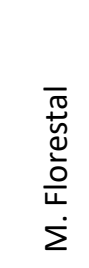 & $\begin{array}{l}\frac{n}{\pi} \\
\stackrel{0}{*} \\
0\end{array}$ & $\begin{array}{l}\frac{\mathbb{0}}{\xi} \\
\frac{2}{2} \\
\frac{1}{d} \\
z\end{array}$ & $\begin{array}{l}\bar{\pi} \\
\stackrel{0}{\circ} \\
\end{array}$ \\
\hline $\begin{array}{l}\text { Barão de } \\
\text { Cotegipe }\end{array}$ & 1039 & 0,29 & 82,58 & 0,10 & 0,10 & - & - & - & 2,11 & 3,75 & 11,07 & 100 \\
\hline Sertão & 880 & 1,36 & 35,68 & 53,18 & 0,23 & 0,34 & 0,23 & 0,23 & 1,02 & 1,70 & 6,02 & 100 \\
\hline Viadutos & 839 & 5,96 & 28,72 & 38,86 & 1,91 & 1,19 & 2,62 & 0,12 & 3,21 & 2,74 & 14,66 & 100 \\
\hline
\end{tabular}

Fonte: Censo Agropecuário (2017).

A rotação de cultura foi realizada em $82,58 \%$ dos estabelecimentos de Barão de Cotegipe, $35,68 \%$ em Sertão e $28,72 \%$ em Viadutos. Essas técnicas podem estar ligadas às condições de relevo, que podem facilitar ou dificultar o uso de mecanização para o manejo das culturas de soja e milho, que é a modalidade de rotação de culturas mais utilizada. A adoção desse procedimento, assim como o uso do pousio/descanso, que não demandam investimentos financeiros, é uma prática rotineira na região. No caso da rotação de culturas, os cultivos são intercalados com milho e soja e com a plantio de aveia no inverno como medida de cobertura de solo. As técnicas que exigem algum tipo de investimento financeiro (proteção de 
encostas, recuperação de mata ciliar e de nascentes, estruturação de voçorocas) tiveram adesão reduzida entre os agricultores.

O total de municípios pesquisados nas modalidades (proteção de encostas, recuperação de APP, recuperação de nascentes e estrutura de voçorocas) apanhadas pelo IBGE chegaram a $6,97 \%$, enquanto nos dados da pesquisa foram encontrados $11,1 \%$.

A pesquisa levantou dados sobre as práticas conservacionistas adotadas pelos agricultores familiares em seus estabelecimentos e mostradas na Figura 1. As informações indicam que o terraceamento representou 1,4\%, o controle de pragas e doenças e a adubação orgânica com 2,2\%, a adubação verde e orgânica com 4,3\%, a recuperação de nascentes representou $11,2 \%$, o percentual com reflorestamento foi de $13 \%$, a rotação de culturas foi encontrada em $28,9 \%$ dos estabelecimentos rurais e o plantio direto com $32,5 \%$ da amostra.

Figura 1 - Adoção de práticas conservacionistas nos estabelecimentos pesquisados

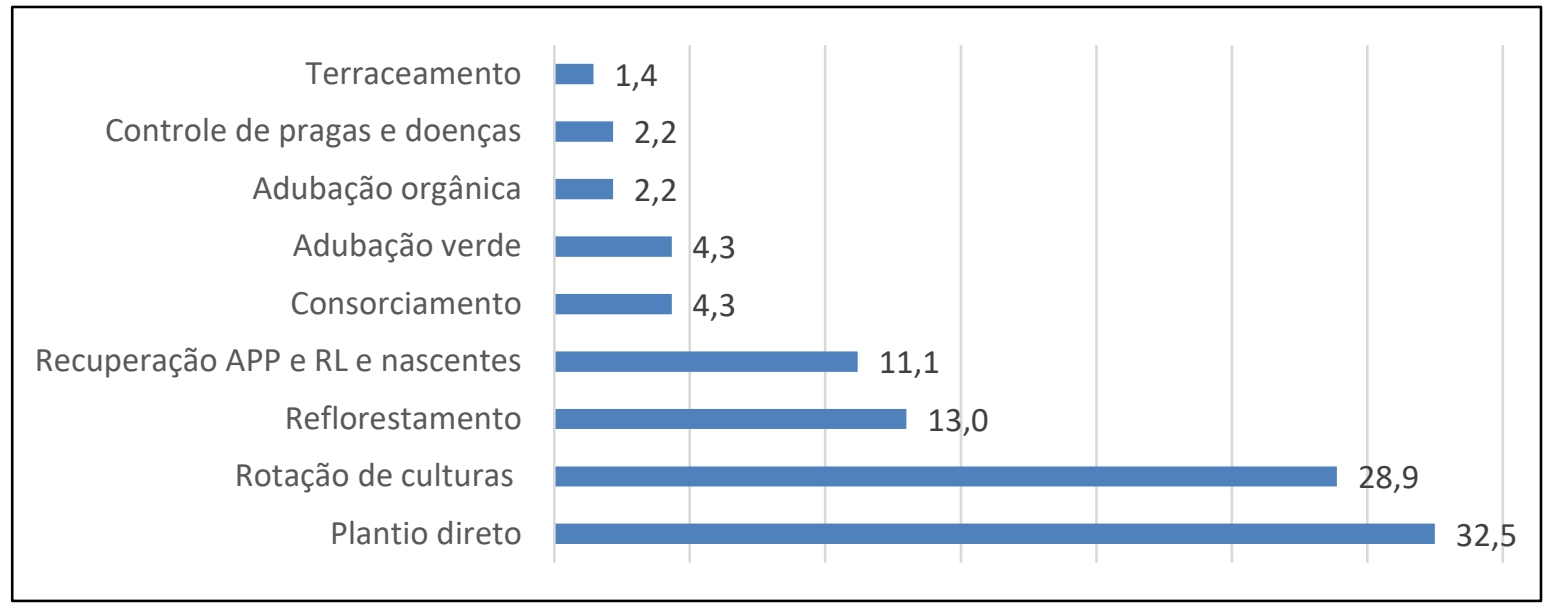

Fonte: Dados de Pesquisa (2019).

Todas as iniciativas acima elencadas fazem parte daquelas práticas consagradas há décadas pela ciência agronômica (adubação orgânica e verde e consorciamento) e que demandam poucos investimentos. Mas, mesmo assim, elas têm baixa adesão entre aos agricultores. O reflorestamento (basicamente representado na modalidade na modalidade de poupança florestal, pressupõe exploração comercial) representa 13,0\% da amostra. As técnicas que demandam algum tipo de investimento financeiro mais expressivo, ou que ainda são incipientes em termos de oferta, a adesão não é expressiva (como o controle alternativo de pragas e doenças e terraceamento). Os investimentos em recuperação de APP, RL e recuperação de nascentes tende a estar relacionados com as multas notificadas por infração ambiental. A rotação de culturas e plantio direto tiveram adesão majoritária em virtude da 
adoção do binômio soja e milho, inerente ao sistema produtivo.

\section{Considerações Finais}

A problemática que norteou este artigo visou refletir sobre as necessidades de ingresso de renda extraordinária nos estabelecimentos dos agricultores familiares, que, de alguma forma, estão relativizando as demandas da sustentabilidade ambiental, no desenvolvimento das atividades agropecuárias realizadas nos estabelecimentos rurais pesquisados nos municípios de Sertão, Barão do Cotegipe e Viadutos, localizados na região do Alto Uruguai do estado do Rio Grande do Sul.

As conclusões anotadas permite aludir que a adesão e a adoção de práticas agrícolas mais amigáveis às demandas ambientais dos estabelecimentos fazem parte do escopo tradicional de técnicas agronômicas consolidadas, (rotação de culturas e plantio direto), que não exigem a alocação de investimentos financeiros por estarem integradas aos sistemas de produção e que, por isso, se tornaram massivas entre os agricultores pesquisados. As evidências sugerem que os agricultores estão reproduzindo o padrão de desenvolvimento agrícola dominante em busca, especialmente, de ingressos econômicos. Dessa forma, os imperativos de maior proteção aos ativos ambientais, aos cuidados com água, uso e conservação de solos e cobertura da vegetação nativa, especialmente, na manutenção e recomposição da biodiversidade, estão sendo desconsiderados.

Foi possível verificar que é baixo o nível de interesse e de investimentos dos agricultores na área ambiental, e independe dos níveis de renda, e quando ocorre é por opção em investimentos na modalidade de poupança florestal, vista como possibilidade de exploração comercial dos produtos madeireiros em áreas inadequadas à exploração agrícola em decorrência de infrações e multas ambientais. A baixa adesão aos investimentos ambientais em proteção, conservação e recuperação de ativos e bens naturais, pode ser justificada pelo desconhecimento, negligência da fiscalização, desinteresse dos agricultores, ausência de políticas de suporte instituídas e financiadas pelo Estado, ou ainda por fragilidade estrutural na geração de renda na maioria dos estabelecimentos. Isso ocorre na medida em que, a preocupação central é produzir excedentes econômicos por meio das atividades agropecuárias, a fim de preservar e manter em operação o estabelecimento e viabilizar a sobrevivência e manutenção da família.

Dessa forma, as opções adotadas pelos agricultores familiares na administração e 
gestão dos estabelecimentos rurais, revelam que os agricultores leem, interpretam a agem como atores/agentes, considerando os constrangimentos e possibilidades, ao converter os ativos e informações disponíveis, visando a reprodução social e material da família e do estabelecimento.

\section{Referências}

ABRAMOVAY, R. O paradigma do capitalismo agrário em questão. São Paulo: Edusp, 2012. ALVES, E.; ROCHA, D. D. P. Ganhar tempo é possivel? In: GASQUES, J. G.; FILHO, J. E. R. V.; NAVARRO, Z. A agricultura brasileira: desempenho, desafios e perspectivas. Brasília: IPEA, 2010. p. 275-290.

AQUINO, J.; SCHNEIDER, S. O Pronaf e o desenvolvimento rural brasileiro: avanços, contradições e desafios para o futuro. In: GRISA, K.; SCHNEIDER, S. Políticas públicas de desenvolvimento rural no Brasil. Porto Alegre: Editora da UFRGS, 2015. p. 53-81.

AUDITORIA CIDADÃ DA DÍVIDA, 2018. Boletim Informativo, ano 1, volume 1 - 2018. Disponível em: <http://www.auditoriacidada.org.br/blog/2018/numeros-da-divida/>. Acesso em: 2 mai. 2019.

BERNSTEIN, H. Dinâmicas de classe e mudanças agrárias. São Paulo: Editora Unesp, 2011.

BOURDIEU, P. Razões práticas: sobre a teoria da ação. Campinas: Papirus, 1996.

. Meditações pascalianas. Rio de Janeiro: Bertrand Brasil, 2001.

BRASIL. Lei 12.512 de 14 de outubro de 2011. Institui o Programa de Apoio à Conservação Ambiental e o Programa de Fomento às Atividades Produtivas Rurais, 2011. Disponível em: <http://www.planalto.gov.br/ccivil_03/_Ato2011-2014/2011/Lei/L12512.htm>. Acesso em: 28 mai. 2019.

BRUM, A. J. Modernização da agricultura no Planalto Gaúcho. Ijuí: FIDENE, 1983.

BUAINAIN, A. M. et al. Sete teses sobre o mundo rural brasileiro. Revista de Política Agrícola, Brasília, 22, n. 2, abr/jun. 2013. p. 105-121.

. et al. O mundo rural no Brasil do século 21: a formação de um novo padrão agrário e agrícola. Brasília: Embrapa, 2014.

.; GARCIA, R. Os pequenos produtores rurais mais pobres ainda tem alguma chance como agricultores? In: NAVARRO, Z.; CAMPOS, S. K. A pequena produção rural e as tendências do desenvolvimento agrário brasileiro: ganhar tempo é possível? Brasília: Centro de Gestão de Estudos Estratégicos, 2013. p. 29-70.

BURSZTYN, M.; BURSZTYN, M. A. Fundamentos de política e gestão ambiental: os caminhos do desenvolvimento sustentável. Rio de Janeiro: Garamond, 2012. 
.; PERSEGONA, M. A grande transformacao ambiental: uma cronologia da dialética homem-natureza. Rio de Janeiro: Garamond, 2008.

CARAVALHEIRO, E. M.; GARCEZ, D. Da perspectiva orientada a ator ao processo de mercantilização: o caso da produção de banana ecológica no litoral norte do Rio Grande do Sul. XLV Congresso Sociedade Brasileira de Economia, Administração e Sociologia Rural. Londrina. 2007.

COMISSÃO MUNDIAL SOBRE MEIO AMBIENTE E DESENVOLVIMENTO. Nosso Futuro Comum. Rio de Janeiro: Editora da FGV, 1991.

COMPANHIA NACIONAL DE ABASTECIMENTO. Acompanhamento da Safra Brasileira - Grãos. Conab, 2019. Disponível em: <https://www.conab.gov.br/info-agro/safras/graos>. Acesso em: 19 mai 2019.

CONTERATO, M. A. Dinâmicas regionais de desenvolvimento rural e estilos de agricultura familiar: uma análise a partir do Rio Grande do Sul. Tese de doutorado. Programa de PósGraduação em Desenvolvimento Rural. Faculdade de Ciências Econômicas. Universidade Federal do Rio Grande do Sul (UFRGS). Porto Alegre: 2008.

. et al. Mercantilização e mercados: a construção da diversidade da agricultura na ruralidade contemporânea. In: SCHNEIDER, S.; GAZOLLA, M. Os atores do Desenvolvimento Rural: perspectivas teóricas e práticas sociais. Porto Alegre: Editora da UFRGS, 2011. p. 67-89. DOWBOR, L. Democracia econômica: um passeio pelas teorias. Fortaleza: Banco do Nordeste, 2007.

GARCIA JÚNIOR, A. O Sul: caminho do roçado; estratégias de reprodução camponesa e transformação social. São Paulo: Marco Zero. Universiade de Brasília, v. MCf-CNPq, 1989. 286 p.

GASQUES, J. G.; BASTOS, E. T. Gastos públicos e o desenvolvimento da agropecuária brasileira. In: ANTÔNIO MÁRCIO BUAINAIN, E. A.; JOSÉ MARIA SILVEIRA, Z. N. O mundo rural no Brasil do século 21: a formação de um novo padrão agrário e agrícola. Brasília: Embrapa, 2014. p. 866890.

GAZOLLA, M. Agricultura familiar, segurança alimentar e políticas públicas: uma análise a partir da produção para o autoconsumo no território do Alto Uruguai (RS). Dissertação de mestrado. Programa de Pós-Graduação em Desenvolvimento Rural. Faculdade de Ciências Econômicas. Universidade Federal do Rio Grande do Sul (UFRGS). Porto Alegre: 2004.

GIBBS, J. Planeta dos humanos. Youtube, 2020. Disponivel em: <https://www.youtube.com/watch?v=VKNTrFKju3g>. Acesso em: 19 mai 2020.

GIDDENS, A. A constituição da sociedade. São Paulo: Martins Fontes, 2003.

GUEDES, A. C.; CAZELLA, A. A.; CAPELLESSO, A. J. O arrendamento de terras no Brasil: subsídios para políticas públicas. Revista Grifos, Chapecó, n. 44, 2018.

INSTITUTO BRASILEIRO DE GEOGRAFIA E ESTATÍ́STICA. Censo 2010 - Rio Grande do Sul. 2010. Disponível em: 
<https://ww2.ibge.gov.br/home/estatistica/populacao/censo2010/tabelas_pdf/total_populaca o_rio_grande_do_sul.pdf>. Acesso em: 7 abr. 2019.

. Censo Agropecuário 2017. 2017. Disponível em:

<https://agenciadenoticias.ibge.gov.br/agencia-sala-de-imprensa/2013-agencia-de-

noticias/releases/21905-censo-agro-2017-resultados-preliminares-mostram-queda-de-2-0-nonumero-de-estabelecimentos-e-alta-de-5-na-area-total>. Acesso em: 28 mai. 2019.

JEAN, B. A forma social da agricultura familiar contemporânea: sobrevivência ou criação da economia moderna. Cadernos de Sociologia, Porto Alegre, v. 6, p. 51-75, 1994.

LEFF, E. Ecologia y capital: racionalidade ambiental, democracia participativa y desarollo sustentable. Mexico: Siglo Veintiuno, 1986.

LONG, N. Introdução à sociologia do desenvolvimento rural. Rio de Janeiro: Zahar, 1982. 370 p. . Development sociology: actor perspectives. London: Routlege, 2001. 293 p. . Sociología del desarrollo: una perspectiva centrada en el actor. México: Centro de Investigaciones y Estudios Superiores en Antropología Social: El Colegio de San Luis, 2007. 504 p.

MARTINS, R. C. A construção social do valor econômico da água: estudo sociológico sobre agricultura, ruralidade e valoração ambiental no estado de São Paulo. Universidade de São Paulo. São Carlos. 2004.

MONSMA, K. Repensando a escolha racional e a teoria da agência: fazendeiro de gado e capatazes no século XIX. Revista Brasileira de Ciências Sociais, São Paulo, 15, n. 43, jun 2000. p. 83-11.

MOSCOVICl, S. A máquina de fazer deuses. Rio Janeiro: Imago, 1990.

NAVARRO, Z. O mundo rural no novo século: um ensaio de interpretação. In: FILHO, J. E. R. V.; GASQUES, J. G.; CARVALHO, A. X. Y. D. Agricultura, transformação produtiva e sustentabilidade. Brasília: IPEA, 2016. p. 25-64.

. Desenvolvimento rural no Brasil: os limites do passado e os caminhos do futuro. Estudos Avançados, 15, n. 43, 2001. p. 83-100.

. ; PEDROSO, M. T. A agricultura familiar no Brasil: da promessa inicial aos impasses do presente. Fortaleza, p. 7-20, ou/dez 2014. Disponível em:

<http://www.bnb.gov.br/projwebren/Exec/artigoRenPDF.aspx?cd_artigo_ren=1444>. Acesso em: 16 mai. 2019.

.; PEDROSO, M. T. M. Agricultua familiar: é preciso mudar para avançar. Texto para Discussão, Brasília, v. 42, 2011.

NIEDERLE, P. Mercantilização, estilos de agricultura e estratégias reprodutivas dos agricultores familiares de Salvador das Missões (RS). Dissertação de mestrado. Programa de Pós-Graduação em Desenvolvimento Rural. Faculdade de Ciências Econômicas. Universidade Federal do Rio Grande do Sul (UFRGS). Porto Alegre: 2007. 
OLIVEIRA, W. M. D.; FILHO, J. E. R. V. Sucessão dos negócios na agricultura: experiências internacionais e políticas públicas. IPEA, 2019. Disponível em:

<http://www.ipea.gov.br/portal/images/stories/PDFs/TDs/td_2448.pdf>. Acesso em: 28 abr. 2019.

PLOEG, J. D. V. D. Labor, markets, and agricultural production. Boulder: Westview Press, 1990. . Ecología, campesinato y historia. Madrid: Las Ediciones de la Piqueta, 1992. p. 153$195 \mathrm{p}$.

POLANYI, K. A grande transformação: as origens da nossa época. Rio de Janeiro: Elsevier, 2000.

SCHMIED-KOWARZIK, W. A relação dialética do homem com a natureza: estudos filosóficos sobre o problema da natureza em Karl Marx. Cascavel: Eduunioeste, 2019. 113 p.

SCHNEIDER, S.; GAZOLLA, M. Os atores entram em cena. In: SCHNEIDER, S.; GAZOLLA, M. Os atores do Desenvolvimento Rural: perspectivas teóricas e práticas sociais. [S.I.]: Editora da UFRGS, 2011. p. 11-17.

SOUZA, G. S.; ET AL. Um modelo de produção para a agricultura brasileira e a importância da pesquisa da Embrapa. Brasília: Embrapa (SGE). Embrapa (SGE). Brasília. 2012. manuscrito não publicado.

TOLEDO, E. N. B. O Pronaf em Salvador das Missões (RS): contradições de uma política de crédito. Dissertação de Mestrado. Programa de Pós-Graduação em Desenvolvimento Rural. Faculdade de Ciências Econômicas. Universidade Federal do Rio Grande do Sul. Porto Alegre: 2009.

. A monetarização da vida social e a gramática econômica da agricultura familiar: acumulação e sustentabilidade. Tese de Doutorado. Centro de Desenvolvimento Sustentável. Universidade de Brasília UnB). Brasília, p. 308. 2017. 